\title{
The other client
}

\section{Information training for administrators pays dividends for the library}

\author{
by Stuart Basefsky
}

W hen research libraries focus on the topic of client orientation, they normally refer to faculty and students. Meeting the needs of research and the curriculum are what research libraries are all about. No one argues with this objective. However, at the Catherwood Library at Cornell's School of Industrial and Labor Relations, client orientation has been stretched to include the needs of administrators. In turn, administrators are developing a new appreciation of the value libraries bring to campus.

Reference Librarians Stuart Basefsky, Deborah Joseph, and Suzanne Cohen are conducting training sessions for Cornell's Office of Human Resources (OHR) and other administrative units. In an effort to bring the library's strengths in line with the mission of the university, administrators are being taught how to use the latest information tools, including leading clatabases, Internet services, and existing print and electronic practitioner materials provided by the library. The idea behind the training sessions is to:

- increase the productivity of administrators by empowering them with the ability to use sophisticated information sources. This includes training in library research methods and multitasking (how to cut and paste from one or several sources into word processing or e-mail programs), with an eye toward production of reports and memoranda;

- enhance administrators' creative alternatives by acquainting them with an enlarged scope of information sources, ideas, and communication processes; and

- demonstrate that the library can be an active player in making the university more competitive by providing training and consulting services.

Catherwood Library is particularly well equipped to provide this kind of service. It has the foremost collection of any North American university on workplace issues. Other libraries may consider doing the same. However, while any university library can provide similar services, semiprofessional and professional school libraries may be more comfortable in extending themselves in this direction.

When universities speak of being competitive, they usually mean that they want better recruitment of faculty and students; more success in getting grants and alumni support; more positive publicity; and good working conditions and benefits. All of these issues are better addressed with good information sources and people who know how to use them.

Libraries can train administrators to be better political lobbyists in more efficient ways; to be better monitors of information about alumni; to be more aware of grant and foundation resources; and to be cognizant of new trends in campus services. These training sessions have met with the following kind of response from a Cornell administrator, "I am writing to tell you that the HR Online

\section{About the author}


workshops presented to OHR and some of our 'affiliates' were an unqualified success! I continue to hear praise for the information presented and the on-the-job usefulness of this particular workshop. . .."

Research libraries ought to consider themselves the "special library" for the university administration. Any library not pushing its client institution forward can be perceived as holding it back.

It is important, therefore, to pay attention to the administration as the "other client." Ironically, this often-ignored client is the one who pays the bills. If the administration

\section{Research libraries ought to}

consider themselves the "special

library" for the university

administration. Any library not

pushing its client institution

forward can be perceived as

holding it back.

knows how valuable the library is from its own experience, those bills are more likely to get paid.
(The library's Web site .. cont. from page 99) available to distance students? What, if anything, does it cost? Provide an online form for making ILL/document delivery requests.

\section{Reference services}

Don't make distance students phone for reference help-they probably won't. Provide e-mail service, whether you have designated one librarian or all your subject specialists to provide reference for distance learners. Let them know whether and how they can receive in-depth online consultations.

\section{Accessing online databases}

Which databases can students access remotely? Must they have an Internet account from your school or can they access the databases using any Internet service provider? Tell them how to get an account from your school and note that it may involve longdistance charges for out-of-area users. If you have a proxy server for remote access, give them instructions on how to access it. Include an e-mail address and a phone number for technical help-and expect to get at least e-mail. When you've identified a technical problem and solution, add it to the instructions or to a troubleshooting section.

If you are able to provide access to only a subset of the databases, suggest alternatives. Will you provide letters of introduction so that students can use their local college or university libraries? Will you run searches for students, and if so, what are the parameters of that service? Encourage students to e-mail you for research assistance if they cannot access your databases, as you may be able to suggest other resources that will suffice.

\section{Web site organization}

Putting all this information in one place, on a distance learners page, is efficient and will be easy to update. Remember, however, that Web users are accustomed to following different paths to reach the same information; they will not necessarily start with the distance learners page. For example, a distance learner looking for borrowing policies might start on the circulation Web page. Therefore, on the circulation page, create a "circulation for distance learners" link to the circulation section of your distance learners page.

In those instances where policies are equal or very similar for on-campus and distance students, you may wish to say so, in addition to providing a referring link. For example: "The online ILL form may be used by oncampus and distance students with a current university ID."

In creating multiple approaches to the same information, the challenges are to provide useful, but not excessive, redundancy and to avoid conflicting information. As policies change, comb the site to make sure information is updated throughout; if you have a database-driven site, you need only to update the information once in the database. The creation of a distance learners page, with links to it throughout your Web site, is the easiest way to meet these challenges.

And although you want to avoid forcing distance students to telephone you for help or information, provide phone numbers just in case they want to. 


\section{BLACKWELL'S}

\section{BOOK SERVICES}

Blackwell's Book Services is committed to excellence in bookselling, cataloging quality, and a wide variety of associated book processing services, tailored

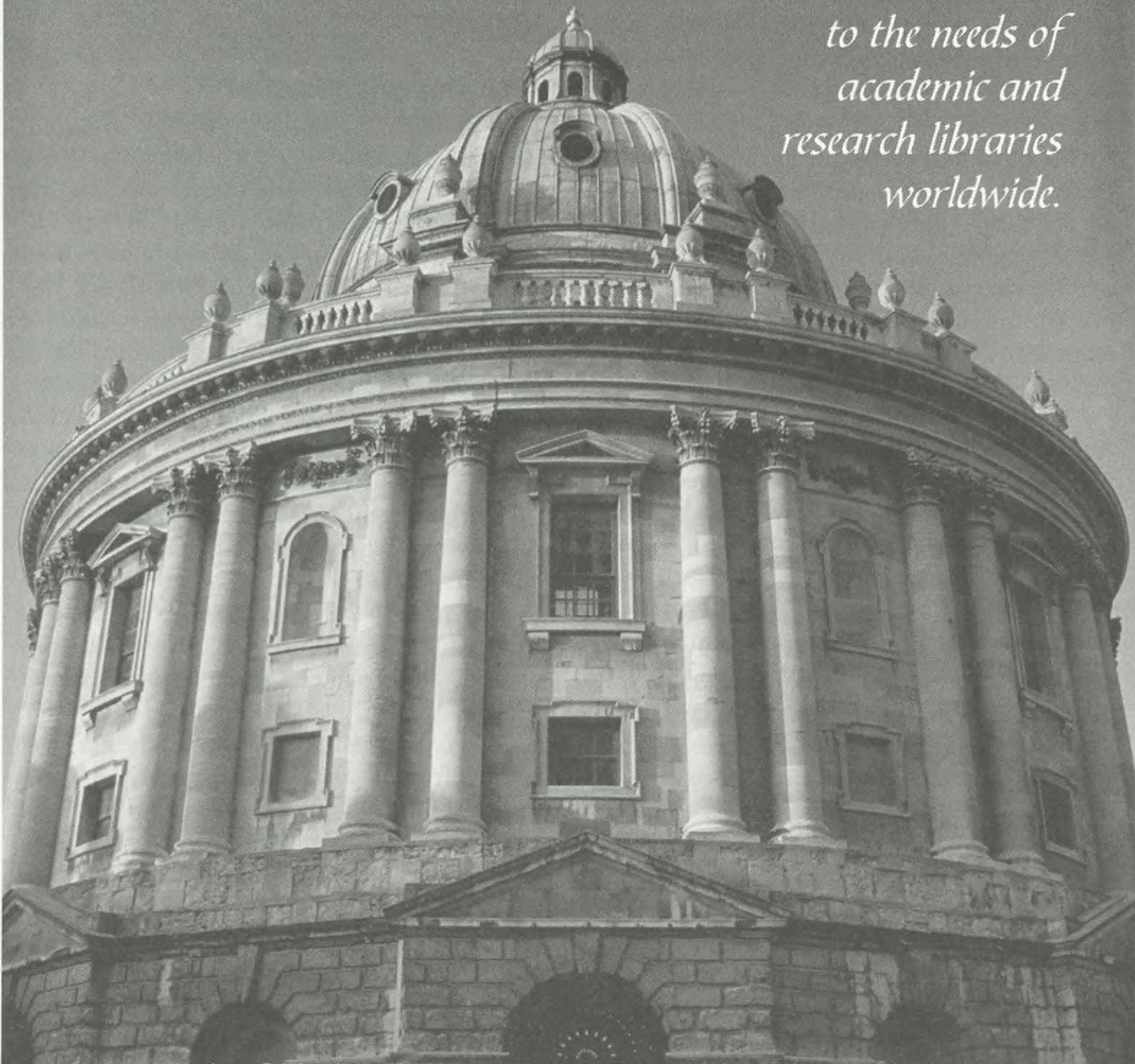

Contact mktg@blackwell.com, 1-800-547-6426, http://www.blackwell.com 